\title{
OBITUARY
}

\section{Dudley Williams, May 25, 1937-November 3, 2010}

$\mathrm{D}$ udley Williams, who made many pioneering contributions to organic mass spectrometry, died recently at the age of 73. After a Ph.D. in Leeds, UK, working on Vitamin D chemistry, Dudley moved to Stanford, California to work with Carl Djerassi (the "father of the contraceptive pill"). In three stunningly productive years, Dudley showed how mass spectrometry and NMR spectroscopy could transform the way that organic chemists worked. His textbooks, reviews, research papers, and lectures revolutionised the practice of organic chemistry over the following 10 years.

In 1964 he was appointed by Lord Todd to a junior academic position in the Chemistry Department at Cambridge, where he remained until his retirement in 2004. He made it a condition of his appointment that the Department installed top-quality nuclear magnetic resonance (NMR) and mass spectrometers to bring it into line with its American competitors. For many years, he continued developing new techniques to make NMR and mass spectrometry into ever more powerful tools for determining chemical structures and for probing chemical properties.

With more than 350 papers to his name, Dudley became one of the most cited chemists in the UK and was elected a Fellow of the Royal Society in 1983. Some of his most cited work were published in the early 1980s in which he described early applications of fast atom bombardment mass spectrometry to polar molecules and was able to demonstrate both $\mathrm{C}$ - and $\mathrm{N}$-terminal peptide sequencing.

In addition to his many notable achievements, Dudley was most proud of his academic family. His group included many scientists who have gone on to have independent careers in mass spectrometry, including Ann Dell, Howard Morris, Graham Cooks, and Carol Robinson. His research group interactions were typified by his sense of humor, his lengthy discussions about the meaning and origins of life, hard-fought badminton and squash tournaments, and his imaginative research questions. He gave up playing squash in his sixties

Correspondence to: Carol Robinson ; e-mail: carol.robinson@chem.ox.ac.uk

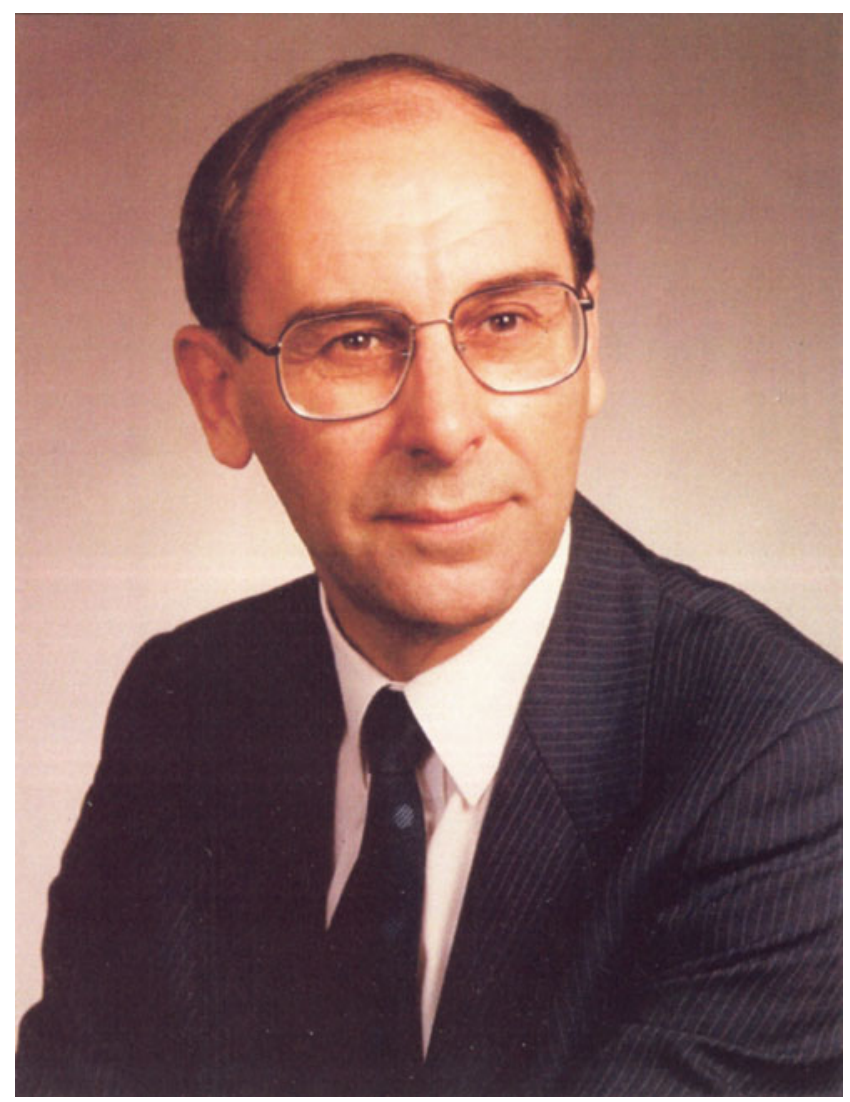

when both hip joints were replaced. Robbed of mobility and energy, he retired but remained active, publishing his last research paper on noncovalent interactions in Current Opinion in October 2010. He was an excellent pianist and continued to enjoy music, a life long passion, well into his retirement.

His peers and fellow mass spectrometrists always looked forward to meeting him at ASMS conferences and other venues in North America and Europe. There was always an oppor- 


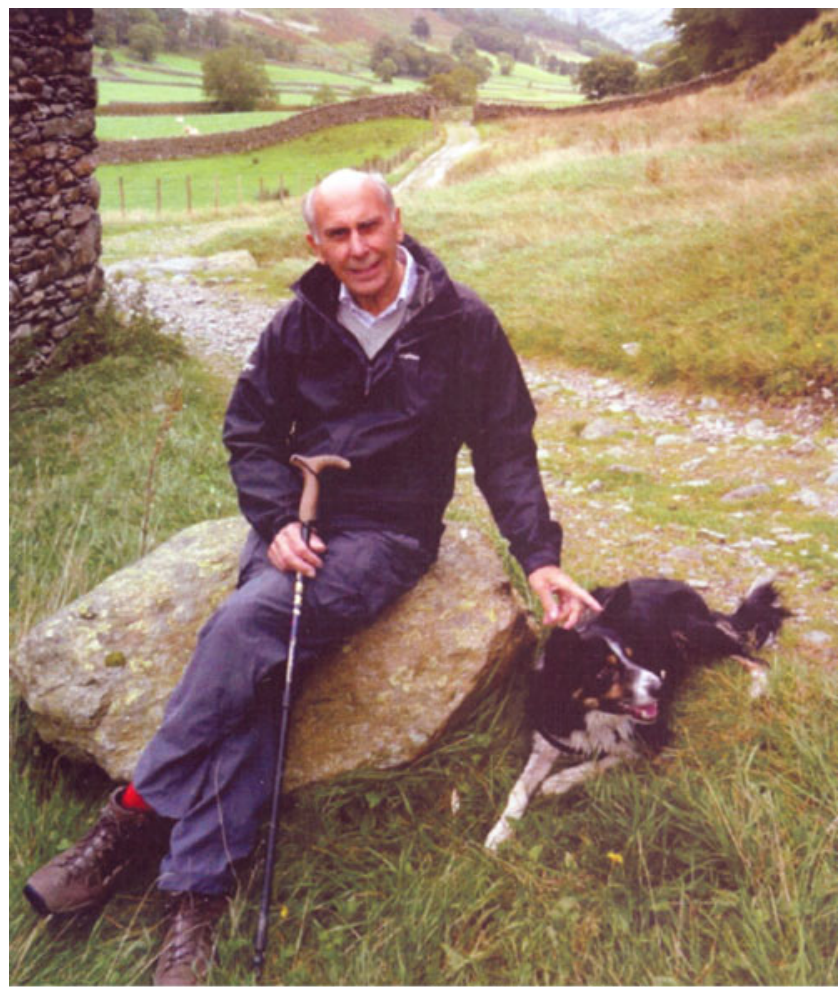

15 September 2010, Grisedale, Lake District tunity to profit from his many insights in chemistry. Even more pleasant, perhaps, were the sharing of stories, trading barbs, and experiencing his clever sense of humor and caustic wit.

Very sadly, Dudley was diagnosed with an aggressive carcinoma of the liver in October 2010 and died in November 2010 . He is survived by his wife Pat, whom he married in 1963, and by their two sons. His scientific legacy, that of the many academics who worked with him and have gone to have successful academic careers, lives on. His humanity and ability to accept students and researchers from all different walks of life were a hallmark of his research group and one from which I will be eternally grateful

Carol V. Robinson Critical Insight Editor, JASMS University of Oxford Oxford,UK 